\title{
A gazdasági teljesítmény és a munkanélküliség területi egyenlőtlenségeinek kapcsolata
}

\section{Relations between economic performance and spatial disparities of unemployment}

\author{
CZALLER LÁSZLÓ
}

KULCSSZAVAK: munkanélküliség, gazdasági teljesítmény, területi egyenlőtlenség, kointegráció

ABSZTRAKT: A fejlett piacgazdaságokban a makrogazdasági teljesítmény és a munkapiacok területi különbségei között fennálló egyensúlyi kapcsolatok az elmúlt évtizedekben több helyütt bizonyítást nyertek. Jelen tanulmányban azt vizsgálom, hogy tekintettel a fiatal piacgazdasági környezetre, Magyarországon az elmúlt időszak tapasztalatai alapján igazolható-e ez a kapcsolat. Ennek érdekében a gazdasági teljesítményt közelítő munkanélküliség és egyenlőtlenségi mutatóinak hosszú idősorait korrelációszámítás és a kointegrációs kapcsolatok kimutatására alkalmas vektor-hibakorrekciós modellek segítségével elemzem, melyek eredményei az idősor egészére nézve egyértelmủen utalnak a feltételezett kapcsolatok hiányára. A gazdaságtörténeti megfontolásból kettébontott idősorokra megismételt tesztek szintén nem nyújtanak egyértelmű bizonyítékot a szóban forgó kapcsolat létezésére. Úgy tűnik tehát, hogy az elhúzódó gazdasági átalakulás folyamatai és az erőteljes állami beavatkozások nem adtak teret a jelenség kibontakozásának. A téma jövőbeni vizsgálata megalapozott, tekintettel a piacgazdasági időszakból származó idősorok rövidségére, valamint a 2008-as válság egyelőre ismeretlen utóhatásaira.

KEYWORDS: unemployment, economic performance, spatial disparities, cointegration

ABSTRACT: Over the past two decades, there has been a notable similarity across Hungarian counties in the changes in the unemployment rate. During the transformational recession and more recently - after the financial crisis of 2008, all of the counties experienced the same rise in the unemployment rate, while regional disparities narrowed. However, during the economic recovery after the first recession, the disparities widened. These patterns suggest the existence of an equilibrium relationship between economic performance and spatial disparities of unemployment, which has been described for several countries with fully developed market economies, but so far has not been analysed in the situation of an economic transformation following a change of the political system.

This study attempts to detect the same correspondence between economic performance and spatial disparities of unemployment, examining the experiences of the first 21 years after the change of the political system. To do this, econometrics-based empirical investigation, including tests for correlation and cointegration were used. After testing for non-stationarity in the trends of the indicators of spatial disparities and the national unemployment rate, taken as a proxy of economic performance, the vector error correction approach was applied to test for cointegration

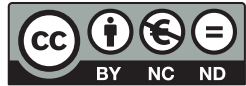


between the variables. Although the results exhibit no unambiguous evidence of the relationship for the time series as a whole, governmental adjustments could suggest breaks in the trends of the variables. To take this into consideration, the periods before and after the trend break of 2001 were analysed separately, as several governmental adjustments happened around that year which could have modified the relationship. However, repeated tests on the distinctive components of the whole period showed no evidence of the hypothesised correspondence in Hungary, either.

It seems that the processes of slow economic transformation and governmental adjustments did not allow this phenomenon to develop. Considering the shortness of the time series within post-1989 Hungary and the unexpected long-term effects of the recent crises, further investigation will be needed to trace the potential manifestation of such a relation.

\section{Bevezetés}

A területi kutatók körében már évtizedekkel ezelőtt felvetődött az a kérdés, hogy a fejlett piacgazdaságokban létezik-e valamilyen egyensúlyi, hosszú távú kapcsolat a munkanélküliség területi egyenlőtlenségei és a gazdasági ciklusok futása között (Gleave 1987; Martin 1997; Dixon, Shepherd, Thomson 2001). A különféle vizsgálati módszerekkel kimutatott eredmények szerint bizonyos országokban, mint az Egyesült Királyságban, Ausztráliában vagy Finnországban létezik effajta kapcsolat. Hazánkban a rendszerváltás óta eltelt bő két évtized alatt tapasztalt folyamatok is ezt a benyomást keltik. A transzformációs folyamatokkal összefüggésbe hozható gazdasági visszaesés időszakában ugyanis hasonlóan mérséklődtek a regionális egyenlőtlenségek, mint évekkel később, a 2008-ban kitört pénzügyi válság idején. A konszolidálódás időszakában pedig éppen ennek ellenkezője volt megfigyelhető, felerősödtek a területi különbségek, azonos irányú kapcsolatot sejtetve a gazdasági teljesítmény és a munkapiaci differenciák között.

Jelen tanulmányban arra keresem a választ, hogy tekintettel a fiatal piacgazdasági környezetre, Magyarországon az elmúlt időszak tapasztalatai alapján statisztikailag igazolható-e kapcsolat a két folyamat között. Ennek érdekében a rendszerváltozás utáni folyamatok összefoglalása és a vizsgálatba vont változók meghatározása után azok stacionaritását tesztelem, amit egy szokványos korrelációs vizsgálat, valamint a kointegrációs kapcsolatok kimutatására alkalmas vektor-hibakorrekciós modell (VECM) tesztelése követ. A vizsgálatokhoz a Nemzeti Foglalkoztatási Szolgálat (NFSZ) munkaügyi adatait használom fel, melyekből megyei szintre származtatok területi egyenlőtlenségi mutatókat, továbbá amelyekkel a nemzetgazdasági teljesítmény alakulását közelítem. ${ }^{1}$ 


\section{A munkanélküliség térbelisége}

A térben differenciáltan jelentkező munkanélküliség alakulásának hatótényezői hazánkban a rendszerváltás óta széles körben kutatottak, a magyarázó tényezők vizsgálatának bőséges szakirodalma áll rendelkezésre (lásd pl. Schwertner 1994; Ábrahám, Kertesi 1996; Fazekas 1997; Nemes Nagy, Németh 2005).

A politikai rendszerváltással együtt járó transzformációs válság egyik legjellemzőbb folyománya a tömeges munkanélküliség megjelenése volt, amely először a szerkezeti válsággal küzdő térségekben jelent meg, majd némi időbeli késéssel az ország csaknem teljes területén égető problémává vált (Schwertner 1994). Az újonnan létrejött Országos Munkaügyi Központ területi szerveinél történő regisztrációk megugrása mögött általánosságban az állt, hogy az állami szféra mint jóformán kizárólagos foglalkoztató a sorozatos csődök miatt nagyszámú munkaerőt bocsátott ki, melyet a piac kevésbé volt képes felszívni. Közrejátszott az is, hogy az átmenetben felgyorsuló foglalkozási átrétegződési folyamatban az agrár- és ipari szektorokból történő munkaerő-kiszorulással a (piaci) szolgáltatási szektor és a közszféra keresletnövekedése nem volt képes lépést tartani. A válság csúcspontjának munkaerő-piaci szempontból az 1993-as év tekinthető, amikor az NFSZ adatai szerint a munkanélküliek száma meghaladta a félmillió föt, azaz a teljes munkaerő-állomány 11,3\%-át.

Mindezzel egy időben a munkanélküliség térbeliségében is létrejött egy stabil szerkezet; hamar kirajzolódott egy markáns kelet-nyugat kettősség, amelynek hátterében rövid és hosszú lefolyású hatások álltak. Rövid távú hatásként Ábrahám Árpád és Kertesi Gábor (1996) kiemeli, hogy kezdetben a cigányság részaránya és az átlagos iskolázottság erőteljes befolyással bírt a munkanélküliségi egyenlőtlenségek alakulására. Ezt a hatást egészítette ki számos hosszú távú jelenség, többek között a múltban gyökerező ágazati struktúrában és vállalati aktivitásban jelentkező különbségek (Fazekas 1997) vagy a foglalkoztatást dinamizáló külföldi tőke fővárosi és nyugati koncentrálódása. A munkapiaci egyenlőtlenségek magyarázó változói között megjelentek azok a tényezők is, melyek egyben a nyugati tőke telephelyválasztásának legfőbb összetevői, nevezetesen a földrajzi fekvés, az infrastrukturális ellátottság, az erőforrások (köztük a munkaerő) hatékony kiaknázásának lehetősége és egyéb extern hatások. Előtérbe kerültek és máig determináló hatással bírnak a helyzeti és humán adottságok (Nemes Nagy, Németh 2005), merev térszerkezetet, stabil térségi pozíciókat hozva létre.

A megyék tekintetében ezt a jelenséget az 1. ábra érzékelteti. A munkaerőpiacról történő tömeges kilépéssel is jellemezhető stabilizálódási időszakban egyedül Komárom-Esztergom megye tudott tartósan kitörni kezdeti hátrányos helyzetéből, 1997-et követően munkanélküliségi rátája az országos átlag alatt stabilizálódott. Ellenpéldaként Békést lehet említeni, mely a kilencvenes évek első felében még az országos átlaggal mozgott együtt, s kisebb hullámzást követően az ezredforduló után a „lemaradók” között állapodott meg. Szembetűno” 
1. ábra: A munkanélküliségi ráta alakulása a magyar megyékben, 1992-2010

Unemployment rates in the Hungarian counties, 1990-2010

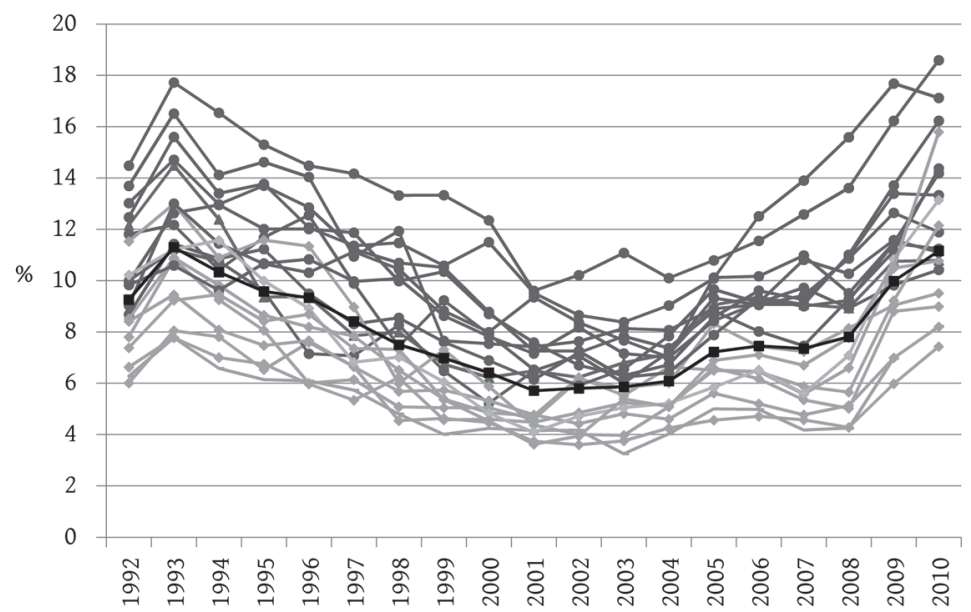

Megjegyzés: Feketével kiemelve az országos munkanélküliségi ráta látható, világosszürkével a tartósan az átlag alatt, sötétszürkével a tartósan az átlag felett tartózkodó megyék találhatók. Adatok forrása: NFSZ.

mindezen felül, hogy az ezredforduló után tendenciaszerűen megnövekvő munkanélküliség alig, ellenben a 2008-ban kitört válság erőteljesen változtatott a megyék helyzetén. Negatív példaként említhető e tekintetben Vas, Veszprém és Zala megye, ahol 2008-at követően az országos átlag fölé emelkedett a munkanélküliségi ráta szintje.

\section{A munkanélküliség területi egyenlőtlenségeinek alakulása}

A munkaerő-piaci tagoltság idősorainak vizsgálatára a nemzetközi szakirodalomban igen széles körben elterjedt módszer, hogy a regionális munkanélküliségi rátákat az országos értékhez hasonlítják (Gleave 1987; Martin 1997; Pehkonen, Tervo 1998). Ennek két legegyszerübb módja, amikor a nemzeti és regionális ráták különbségét vagy arányát veszik, majd ezen értékek időbeni változásából következtetnek a területi egyenlőtlenségek alakulásának irányára. Ezeknél némileg összetettebb mutató azonban a relatív diszperzió mérőszáma, ${ }^{2}$ amely az egyes régiókban megfigyelt munkanélküliségi arányokat viszonyítja ahhoz a feltételezett állapothoz, amikor a munkanélküliség az egész országban homogén módon az országos munkanélküliségi rátának felel meg. A mutató matematikai levezetése egészen egyszerü (Martin 1997, 240):

Definiáljuk $u_{n}$-t és $u_{r}$-t, mint a munkanélküliek számának $\left(U_{n}, U\right)$ a gazdaságilag aktív népesség számához $\left(L_{n^{\prime}} L_{r}\right)$ viszonyított arányát $n$ ország $r$ területegységeiben (esetünkben Magyarország megyéiben): 


$$
u_{n}=\frac{U_{n}}{L_{n}} \text { és } u_{r}=\frac{U_{r}}{L_{r}}
$$

Ha az összes térségben megegyezik $u_{r}$ értéke, úgy az országos érték is megegyezik $u_{r}$-rel, azaz $u_{r}=u_{n}$. Ebben az esetben az egyenlöség felírható $U_{r} / U_{n}=L_{r} / L_{n}$ formában is. Minden egyéb esetben azonban az arány a következő:

$$
\frac{U_{r}}{U_{n}}=\left(\frac{u_{r}}{u_{n}}\right)\left(\frac{L_{r}}{L_{n}}\right)
$$

A relatív diszperzió (RD) mutatószámának lényegi eleme, hogy minden területegységben rámutat a feltételezett teljes földrajzi egyenlőség és a valós helyzet közti különbségre, majd ezek abszolút értékét összegzi:

$$
R D=\sum_{r=1}^{n}\left|\left(\frac{U_{r}}{U_{n}}\right)-\left(\frac{L_{r}}{L_{n}}\right)\right|
$$

A (2) egyenlet (3)-ba történő behelyettesítése és némi átalakítás után a regionális diszperzió képlete a következőképp alakul:

$$
R D=\left(\frac{1}{u_{n}}\right) \sum_{r=1}^{n}\left|\left(\frac{L_{r}}{L_{n}}\right)\left(\frac{u_{r}}{u_{n}}\right)\right|
$$

A (4) képlettel számolható relatív diszperziós mutató alkalmazásának egyik legfóbb előnye, hogy pontos, a Hoover-indexéhez ${ }^{3}$ hasonló tartalom adható neki. Belátható ugyanis, hogy a mutató az országos munkanélküliségi ráta arányában jelzi, hogy hány munkanélkülinek kell a hátrányos helyzetű térségekben állást találni és hány embernek kell elvesztenie állását a fejlettebb területeken ahhoz, hogy a munkanélküliség területi eltérései teljesen eltűnjenek (Dixon, Shepherd, Thomson 2001; Dixon, Mahmood 2007).

A hazai egyenlőtlenségek relatív munkanélküliségi diszperzió segítségével számított idősorait a 2. ábra mutatja, melyen összehasonlításképpen feltüntettem az igen népszerü súlyozott relatív szórás mérőszámát, valamint a munkanélküliség alakulásának országos értékeit. ${ }^{4}$

Szembetűnő, hogy a két, szorosan együtt mozgó egyenlőtlenségi mutató futása az országos munkanélküliségi ráta változásával többé-kevésbé fordított irányú kapcsolatot mutat, ami egybevág több korábbi munka tanulságaival s a bevezetőben említett feltételezéssel. A transzformációs válság időszakában, ahogy 1993-ra csúcsokat ért el a munkanélküliség, úgy mérséklődtek az egyenlőtlenségek, ami a korábban említett rövid távú differenciáló tényezők visszaszorulásával és a hosszú távú kiegyenlítő hatások felerősödésével magyarázható (Ábrahám, Kertesi 1996; Fazekas 1997). A kilencvenes évek második felében tapasztalható munkaerő-piaci rege- 
2. ábra: A megyei munkanélküliségi egyenlőtlenségek alakulása, 1992-2010 Spatial disparities of unemployment amongst counties, 1992-2010

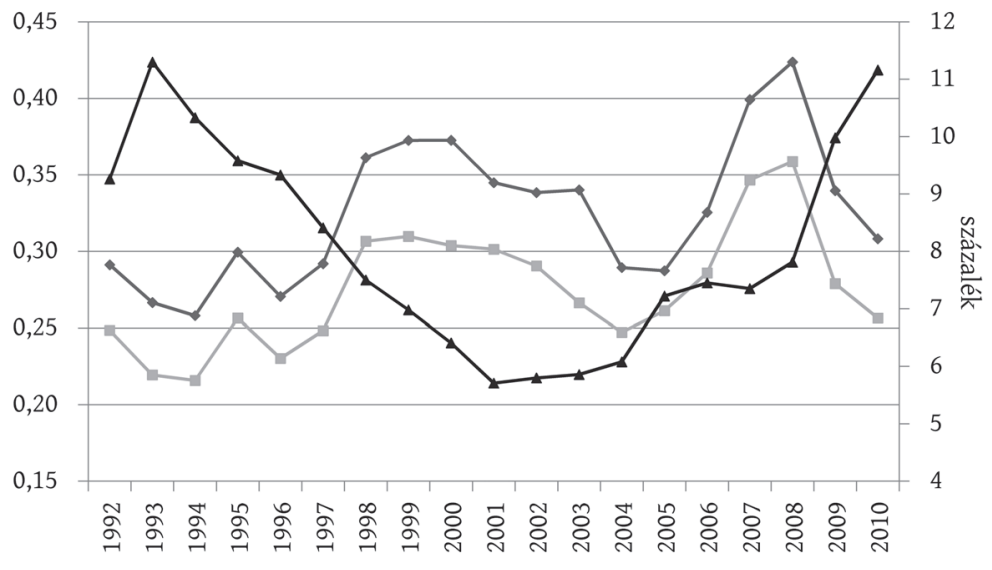

$\rightarrow$ Súlyozott relatív szórás --Relatív diszperzió —Országos munkanélküliségi ráta Megjegyzés: A bal oldali tengely a két egyenlőtlenségi mérőszám, a jobb oldali az országos munkanélküliségi ráta értékeire vonatkozik.

Adatok forrása: NFSZ.

nerálódás a területi különbségek növekedésével járt együtt, 2000-ig mindkét egyenlőtlenségi mutató értéke emelkedett. A munkanélküliség országos szintje 2001-ben érte el minimumát, melyet az elkövetkező három évben lassú ütemü növekedés követett az egyenlőtlenségek csökkenésével párhuzamosan. 2004 után azonban a területi különbségek és az országos munkanélküliség szintje is gyors növekedésnek indult. Az újabb markáns iránybeli változást a 2008-ban kitört világválság okozta, melynek következtében a munkanélküliek száma rohamosan megnőtt, ugyanakkor a területi egyenlőtlenségek meredeken csökkentek. Ennek hátterében az áll, hogy a nyugati országrész exportorientált, külső sokkoknak jobban kitett megyéinek gazdaságát a nemzetközi válság mélyebben érintette, ellentétben a keleti térségekkel és a Balaton környéki idegenforgalmi központokkal, ahol csak kisebb mértékben és némi látenciával volt érzékelhető a visszaesés (Lőcsei 2010).

A különböző okokkal alátámasztható, de végeredményben munkapiaci nivellálódást eredményező két hazai válságidőszak és a köztük lévő átmeneti gazdasági fellendülés felveti tehát a kérdést, hogy létezik-e egyenes irányú kapcsolat az egyenlőtlenségek és a gazdasági teljesítmény változásai között, vagy a múltbéli események csak véletlenül rajzolják ki a változók ilyetén idősorait. Ennek felderítésére a továbbiakban Ron Martin (1997), Robert Dixon és szerzőtársai (2001) valamint Dixon és Mahmood (2007) kutatási módszertanát követve a munkanélküliségi ráta idősorát a gazdasági teljesítmény ciklikusságának mérőszámaként alkalmazom. Ennek alapjául az az empirikus tény szolgál, hogy a munkanélküliségi ráta kontraciklikus jellegủ mutató, azaz a reál-GDP sa- 
ját trendjétől való negatív eltérése esetén a munkanélküliségi ráta saját trendjétől pozitívan tér el, és vice versa (Williamson 2009, 582.).

\section{A munkanélküliségi különbségek és a gazdasági teljesítmény kapcsolata}

A társadalmi folyamatok együttmozgásának legelterjedtebb mérőszáma, a Pearson-féle korrelációs együttható $(p)$ a megyei munkanélküliségi ráták havi bontású idősorai között páronként szignifikáns, közepes erősségű, fordított irányú kapcsolatot feltételez, a relatív diszperzió esetében $p=-0,502$, a súlyozott relatív szórás esetén pedig $p=-0,524$ értékekkel. Idősorok elemzésekor azonban a korreláció korlátozott feltételek mellett alkalmazható. A korrelációs mérőszám alkalmazása megállja a helyét kovarianciastacionárius, azaz időtől független, konstans várható értékü - $E(Y t)=\mu$, állandó varianciájú - $\operatorname{Var}(Y t)=\sigma 2$, valamint kizárólag a $k$ késleltetés mértékétől függő kovarianciájú $\operatorname{Cov}(Y t, Y t-k)=\gamma k$ idősorok esetében, azonban nemstacionárius folyamatok vizsgálatakor hamis eredmények várhatók (Granger, Newbold 1974).

A nemstacionárius folyamatoknak két fajtáját különböztethetjük meg. Trendstacionárius esetben a folyamat determinisztikus trendet tartalmaz, melynek kivonásával stacionárius folyamatot kapunk. Differenciastacionárius folyamat esetén azonban a folyamatot leíró egyenlet autoregresszív tagjai úgynevezett egységgyökö(ke)t tartalmaz(nak), ami meghatározza a folyamat időbeli lefutását. Utóbbi eset szemléltetésére vegyünk egy AR(1) elsőrendü autoregresszív modellt, melyben $Y$ változó $t$ időpontbeli értéke a $(t-1)$ időpontban mért érték segítségével becsülhető:

$$
Y_{t}=\alpha+\beta Y_{t-1}+\varepsilon_{t}
$$

ahol $\varepsilon_{t}$ a hibatag. Az (5) egyenlet az $L$ késleltetési operátor segítségével átírható a következő formába:

$$
(1-\beta \mathrm{L}) Y_{t}=\alpha+\varepsilon_{t}
$$

Ha a $\beta$-paraméter értéke egységnél kisebb, akkor $Y$ múltbeli értékének a $t$ időpontbelire gyakorolt hatása az idő múlásával egyre csökken, amíg $Y_{t}$ el nem éri az $\alpha /(1-\beta)$ határértéket. A $\beta$-paraméter minél inkább közelít 1-hez, a múltbeli hatások annál hosszabb ideig érvényesülnek. Pontosan egységnyi érték esetén pedig a múltbeli hatások sosem hagyják el a rendszert, $Y$ értéke az idő múlásával megnövekszik. ${ }^{5}$

A munkapiaci vizsgálatokban egységgyökökkel jellemezhető maradandó hatásokat okozhatnak többek között különféle kormányzati beavatkozások, a 
szakszervezeti béralku vagy a piaci szektor beruházásainak alakulása is (Kormos, Czeglédi 2008). Ezek a sokkok a munkanélküliség alakulását tartósan befolyásolhatják, ami nemstacionárius idősorokat eredményez. Ahhoz tehát, hogy megbízható eredményeket kapjunk, először az idősorok jellegéről kell információkat nyerni. Mivel a stacionaritás vizsgált változóink idősoraiban vizuális úton nem igazolható, ezért a kiterjesztett Dickey-Fuller-teszt (a továbbiakban ADF) segítségével tesztelem, hogy léteznek-e a modellben determinisztikus trendek vagy az idősor futását tartósan módosító egységgyökök. ${ }^{6}$ Az egységgyöktesztet az országos munkanélküliségi rátára és a két egyenlőtlenségi mutatóra minden esetben kétszer végzem el, egyszer determinisztikus trendek beillesztésével, egyszer pedig anélkül. Az esetleges szélsőségek kiküszöbölése végett az elemzést a változók logaritmikus átalakításával kezdem, melynek eredményeként az ADF-teszt a következő formát ölti:

$$
\ln \left(Y_{j}\right)=\alpha+\beta t+(\rho-1) \ln \left(Y_{j-1}\right)+\sum_{k=1}^{p} \theta \Delta \ln \left(Y_{j-k}\right)+\varepsilon_{j}
$$

ahol $Y_{t}$ a három szóban forgó változó $j$ időpontban, $t$ az időkomponens, $p$ a késleltetett változók száma, $\Delta$ az első differenciát jelöli, $\varepsilon$ pedig a változóktól független fehér zaj. $\alpha, \beta, \theta$ és ( $\rho-1)$ regressziós együtthatók, melyek közül $(\rho-1)=0$ esetén beszélhetünk egységgyökfolyamatról. A tesztek a Schwartz-féle információs kritérium alapján 4 késleltetett értéket tartalmaznak.

Az 1. táblázatban összefoglalt eredmények alapján egyértelmű, hogy a vizsgált változók egyikénél sem utasítható el az egységgyökök létezésének nullhipotézise, a p-értékek meghaladják a szokványos, 1 és 5\%-os szignifikanciaszinteket. A trendek sem számítanak szignifikánsnak, létezésük nem befolyásolja kritikus mértékben a $(\rho-1) t$-statisztikáinak értékeit, azaz determinisztikus trendektől függetlenül elvethető az egységgyök hiányának nullhipotézise. A munkanélküliség esetében a stacionaritás elutasítása esetleg meglepő lehet, hiszen korlátos válto-

1. táblázat: Az országos munkanélküliségi rátára és az egyenlőtlenségi mutatókra számolt ADF-tesztek eredményei

Results of ADF-tests of the national unemployment rate and spatial inequality indices

\begin{tabular}{l|rrrr|rr}
\hline Változók & \multicolumn{4}{|c|}{ 1.teszt } & \multicolumn{2}{c}{ 2. teszt } \\
& \multicolumn{1}{c|}{$(\rho-1)$} & $p$-érték & \multicolumn{1}{c}{$(\beta)$} & $p$-érték & \multicolumn{1}{c}{$(\rho-1)$} & $p$-érték \\
\hline Országos munkanélkü- & $-0,0025$ & 0,9935 & 0,0007 & 0,1224 & $-0,0091$ & 0,8627 \\
$\quad$ liségi ráta & $(-0,1621)$ & & $(1,5499)$ & & $(-0,6183)$ & \\
Relatív diszperzió & $-0,1217$ & 0,2472 & 0,0000 & 0,3235 & $-0,1002$ & 0,1145 \\
& $(-2,6770)$ & & $(0,9895)$ & & $(-2,5095)$ & \\
Súlyozott relatív szórás & $-0,1042$ & 0,3992 & 0,0000 & 0,4148 & $-0,0872$ & 0,1926 \\
& $(-2,3606)$ & & $(0,8170)$ & & $(-2,2407)$ & \\
\hline
\end{tabular}

Megjegyzés: Zárójelben a t-statisztikák értékei olvashatók, ( $\rho-1)$ esetén az Eviews szoftvercsomag a MacKinnon által módosított egyoldalú t-statisztikákat használja. 
zó lévén hosszú távon stacionárius idősorokra számítanánk (Nelson, Plosser 1982). Ugyanez a helyzet a munkanélküliségi egyenlőtlenségekkel is, hiszen ezek szintén korlátos változók. Rövidebb időtávon azonban különféle külső hatások mindkét esetben érvényesíthetik befolyásukat, melyek egyértelmü statisztikai megnyilvánulásai az egységgyökök (illetve közelegységgyökök).

A lefuttatott egységgyöktesztek alapján tehát a változókról egyik esetben sem állíthatjuk kellő bizonyossággal, hogy stacionáriusak lennének, így a korábbi korrelációs vizsgálatok valószínűleg hamis következtetésekhez vezetnek. A kapcsolatok feltárására ezért olyan módszereket szükséges alkalmazni, melyek nem érzékenyek a stacionaritásra. Az egyik járható út a differenciálás, amely a legtöbb esetben csökkenti a változók integráltsági szintjét. Mivel a gazdasági változók többsége I(1), azaz elsőrendű integrált folyamat, ezért egyszerű differenciálással I(0) stacionáriussá lehet tenni a változók idősorait. A differenciált idősorok stacionárius voltának igazolására ismét az ADF-tesztet alkalmaztam (2. táblázat). Az eredmények egységgyökök hiányára utalnak, így tehát a differenciált adatsorok I(0) stacionárius folyamat lévén megfelelnek a korrelációszámítás alkalmazási feltételeinek.

A módosított adatsorok közti korrelációs együtthatók értékei drasztikusan lecsökkennek, a súlyozott relatív szórás esetében már csak p=-0,224, a relatív diszperziónál $p=-0,194$ értékeket kaptam. Ezek tisztán mutatják az eredeti korrelációk hamis voltát, és a feltételezett kapcsolatok hiányát sejtetik.

Az idősorok együttmozgásának vizsgálatára egy másik adekvát, egyszersmind a korrelációszámításnál megbízhatóbb módszer a kointegrációs kapcsolatok feltárása. Ennek lényege, hogy olyan úgynevezett kointegrációs vektorokat keresünk, melyek segítségével az I(1) változók páronként felírhatók egymás lineáris kombinációjaként, amelyek már I(0), azaz stacionárius folyamatok. A kointegrációs kapcsolat feltárására vektor-hibakorrekciós modellt (VECM) alkalmazok, melynek hátterében a következő feltételezések állnak. Adott egy p-ed rendü vektor-autoregresszív VAR(p)-modell, ahol $\alpha$ konstans vektor, $Y_{t}$ a függő változók vektorait jelöli, $\varepsilon_{t}$ a hibatagok vektora.

$$
Y=\alpha+\Phi_{1} Y_{t-1}+\Phi_{2} Y_{t-2}+\ldots+\Phi_{p} Y_{t-p}+\varepsilon_{t}
$$

2. táblázat: Az ADF-teszt eredményei a változók első differenciáira Results of ADF-tests for the first differences of the variables

\begin{tabular}{lrc}
\hline Változók & \multicolumn{1}{c}{$(\rho-1)$} & p-érték \\
\hline Országos munkanélküliségi ráta & $-1,3392$ & 0,0000 \\
& $(-8,9475)$ & \\
Relatív diszperzió & $-1,6809$ & 0,0000 \\
& $(-10,1595)$ & \\
Súlyozott relatív szórás & $-1,7855$ & 0,0000 \\
& $(-10,6757)$ & \\
\hline
\end{tabular}

Megjegyzés: lásd 1. táblázat. 
Igazolható, hogy minden ilyen $\operatorname{VAR}(p)$ felírható VECM-alakban is: ${ }^{7}$

$$
\Delta Y_{t}=\Pi Y+\sum_{i=1}^{p-1} \Phi_{j}^{*} \Delta Y_{t-i}+\varepsilon_{t}
$$

ahol $\Phi^{*}$ és $\Pi$ mátrixok $\Phi$-k függvényei, a következőképpen:

$$
\Pi=-\left(I-\Phi_{1}-\ldots-\Phi_{p}\right)=-\Phi(1) \text { és } \Phi_{j}^{*}=-\sum_{i=j+1}^{p} \Phi_{i}, \text { ahol } j=1,2, \ldots p-1
$$

Clive Granger reprezentációs tételének ${ }^{8}$ következtében, ha adott a függő változók $Y_{t}(n \times 1)$-es mátrixa, ahol $n$ a változók számát - esetünkben kettőt - jelöli, léteznie kell egy olyan $\beta^{\prime}(n \times r)$ mátrixnak, amelynek segítségével felírható egy stacionárius $(r \times 1)$-es $z_{t}=\beta^{\prime} Y_{t}$ vektor, ahol $r$ számossága a hosszú távú kapcsolatot meghatározó kointegrációk számát sejteti. A VECM-modellben $r$ értéke a $\Pi$ mátrix rangjának meghatározásával lehetséges. Ennek tesztelésére a Søren Johansen (1988) által javasolt nyomtesztet $(\eta)$ és legnagyobbsajátérték-tesztet $\left(\lambda_{\text {max }}\right)$ végzem el, melyek nullhipotézise szerint nem létezik kointegrációs kapcsolat. ${ }^{9}$

A 3. táblázat a gazdasági teljesítmény indikátorának számító munkanélküliségi ráta és a két egyenlőtlenségi mutató logaritmikusan transzformált idősorai között elvégzett számítások eredményeit páronként veti össze. Az eredmények nem utalnak kointegrációs kapcsolatra a változók idősorai között; sem a nyom-, sem a legnagyobbsajátérték-teszt alapján nem utasítható el a nullhipotézis, a pértékek messze túllépik a hagyományosan használt szignifikanciaszinteket. Az elvégzett tesztek tehát egyhangúan cáfolják az összefüggést, ez azonban egyáltalán nem jelenti azt, hogy a hipotézis alapjaiban elvetendő. Ennek egyértelműsítésére további vizsgálatok, módosítások szükségesek. Előfordulhat ugyanis, hogy a reálgazdaságot vagy a munkaerőpiacokat ért valamilyen külső sokk eltéríti a kapcsolatot egyensúlyi helyzetéből, amelybe csak évek múltán tér vissza; esetleg a változók trendjeiben olyan tartós strukturális eltolódás vagy törés következik be, amely ellehetetleníti az időszak egészére vonatkozó vizsgálatot. Robert Dixon és szerzőtársai (2001) az utóbbi lehetőséget feltételezve az idősort a törés időpontjában kettévágták, s a két időszakra külön vizsgálták meg az összefüggéseket. Ugyanezen módszerrel vizsgálták a regionális munkanélküliség adatsorainak stacionaritását Michelle Baddaley és szerzőtársai (1998). Mindazonáltal ez a módszer

3. táblázat: A VECM-modell nyom- és legnagyobbsajátérték-tesztjeinek eredményei Results of the trace and maximum eigenvalue tests of the VECM-model

\begin{tabular}{lccrc}
\hline Változópárok & $(\eta)$ & $p$-érték & $\left(\lambda_{\text {max }}\right)$ & $p$-érték \\
\hline $\begin{array}{l}\text { Országos munkanélküliségi ráta - relatív } \\
\quad \text { diszperzió }\end{array}$ & 11,6789 & 0,1730 & 11,1650 & 0,1461 \\
$\begin{array}{l}\text { Országos munkanélküliségi ráta - súlyozott } \\
\text { relatív szórás }\end{array}$ & 8,3200 & 0,4318 & 7,9858 & 0,3802 \\
\hline
\end{tabular}

Megjegyzés: A p-értékeket az EViews szoftvercsomag MacKinnon, Haug és Michelis számításaira alapozza. 
csak abban az esetben alkalmazható, ha a feltételezett trendtörésnek megfelelő elméleti megalapozottsága van, korábbi eseményekkel jól magyarázható és nem utolsó sorban vizuálisan is kivehető. A legtöbb esetben azonban a hatótényezők mivolta ismeretlen vagy megkérdőjelezhető, így a lehetséges strukturális törések felderítése is statisztikai feladattá válik (Christiano 1992). Esetünk abból a szempontból szerencsésnek mondható, hogy egyfajta éles trendtörés a munkanélküliségi ráta éves gyakoriságú idősoraiban intuitíve kivehető, s különféle gazdaságpolitikai, feltételezhetően az egyenlőtlenségekre is ható mechanizmusokkal alátámasztható.

\section{Kointegrációs kapcsolatok tesztelése trendtörések jelenlétében}

Az új évezred kezdetén több olyan, a foglalkoztatást érintő intézkedés is történt, amely a munkapiacok állami szabályozását erősítette, torzítva a piacok azon természetes mechanizmusait, melyek folyományaként a feltételezett kapcsolatok a rendszerváltás után lassan kibontakozhattak volna. Az egyik legfontosabb ilyen intézkedés a minimálbér kétlépcsős, drasztikus mértékű emelése volt 2001-ben, mely a későbbiekben bizonyítottan közrejátszott a foglalkoztatás csökkenésében. Köllő János és Kertesi Gábor többek között arra mutattak rá, hogy a minimálbér emelése azokban a kistérségekben növelte a munkanélküliség szintjét, melyek munkapiaci szempontból már akkor is hátrányos helyzetünek számítottak (Köllő, Kertesi 2004). Ez a hatás elméletileg egyértelműen a területi differenciálódás irányába hat, ami azonban megyei szinten 2004 előtt nem érzékelhető. A 2002-ben kormányt alakító szocialista-liberális koalíció külön minisztériumi apparátust hozott létre a munkaügyek összehangolt kezelésére, valamint ekkor jelent meg először a területi kiegyenlítődés mint foglalkoztatáspolitikai cél (Fazekas, Németh 2005). Ebből az időszakból többek között a közszférát érintő béremelés emelendő ki mint a munkapiaci bérfoglalkoztatási mechanizmusokat befolyásoló, egyszersmind a differenciálódás felerősítésében feltételezhetően komolyabb szerepet játszó intézkedés. Mindezen elméleti megfontolások alapján indokolt az idősort az ezredforduló utáni években - például az első komoly intézkedés után, 2001 végén - szétválasztani, és a két időszakot a már ismertetett módszerekkel külön tesztelni. Így a megújuló környezetben érvényesülő összefüggéseket függetleníteni lehet az azt megelöző időszakban tapasztaltaktól (Dixon, Shepherd, Thomson 2001).

Az idősor kettébontása után elvégzett ADF-tesztek $\beta$-paraméterekre vonatkozó eredményei (4. táblázat) a munkanélküliség országos rátájában a 2. ábráról is egyértelműen kivehető ellenkező irányú determinisztikus trendeket mutatnak. Az egyenlőtlenségi mutatók körében ez azonban csak a 2001-ig tartó időszakra igaz, mégpedig pozitív meredekséggel, ami gyenge utalás a vélt kapcsolatok meglétére. A 2002 és 2010 között eltelt időszakban azonban a trendek 
4. táblázat: A trendtöréssel felbontott időszakok ADF-tesztjei

Results of ADF-tests of the divided time series

\begin{tabular}{lrrrrrrrr}
\hline Változók & \multicolumn{9}{c}{$1992-2001$} & \multicolumn{6}{c}{$2002-2010$} \\
\cline { 2 - 9 } & \multicolumn{1}{c}{$(\rho-1)$} & $p$-érték & \multicolumn{1}{c}{$(\beta)$} & $p$-érték & \multicolumn{1}{c}{$(\rho-1)$} & $p$-érték & \multicolumn{1}{c}{$(\beta)$} & $p$-érték \\
\hline Országos munka- & $-0,2455$ & 0,0294 & $-0,0017$ & 0,0002 & $-0,1572$ & 0,2958 & 0,0011 & 0,0121 \\
nélküliségi ráta & $(-3,6579)$ & & $(-3,8275)$ & & $(-2,5680)$ & & $(2,5561)$ & \\
Relatív diszperzió & $-0,3114$ & 0,0394 & 0,0011 & 0,0046 & $-0,0960$ & 0,7751 & 0,0000 & 0,8404 \\
& $(-3,5438)$ & & $(2,8907)$ & & $(-1,6283)$ & & $(-0,2019)$ & \\
Súlyozott relatív & $-0,2516$ & 0,1679 & 0,0009 & 0,0183 & $-0,0898$ & 0,8230 & 0,0001 & 0,6326 \\
szórás & $(-2,8955)$ & & $(2,3953)$ & & $(-1,5019)$ & & $(-0,4795)$ & \\
\hline
\end{tabular}

Megjegyzés: A késleltetés mértékét minden esetben a Schwartz-féle információs kritérium határozta meg. Zárójelben a t-statisztikák értékei olvashatók, $(\rho-1)$ esetén az Eviews szoftvercsomag a MacKinnon által módosított egyoldalú t-statisztikákat használja.

jelentősége az egyenlőtlenségi mutatóknál visszaszorult, és csak a munkanélküliségi ráta változója esetében maradt szignifikáns. A trendtörést követően az egységgyökök szerepe viszont mindhárom változónál kidomborodott, holott a kezdeti években csak a súlyozott relatív szórásnál volt kimutatható egységgyök. Az ADF-tesztek eredményei alapján feltételezhető tehát, hogy 2001 után a fokozott állami beavatkozás nemcsak a munkanélküliségi trendek fordulatában játszott szerepet, hanem az egyenlőtlenségek alakulását is erősen befolyásolta, elmosva a gazdasági teljesítmény és az egyenlőtlenségek feltételezett törvényszerüsége alapján fennálló fordított irányú trendeket.

A stacionaritásra irányuló egységgyöktesztek megismétlése után a különválasztott időszakokra a korábbiakban már bejáratott korrelációs és kointegrációs vizsgálatokat végzem el, melyek eredményeit az 5. táblázat mutatja. Az idősor két szegmense alapvetően különbözik. Az 1992 és 2001 közötti időszak korrelációs együtthatói az egyenlőtlenségi mutatók és a munkanélküliségi ráta között fordított irányú, közepes erősségủ és minden esetben szignifikáns kapcsolatot jeleznek. A kointegráció tesztjei között már mutatónként és tesztenként is eltérő az eredmény, az országos ráta és a relatív diszperzió között $5 \%$-os szignifikanciaszint mellett a legnagyobbsajátérték-teszt $\left(\lambda_{\max }\right)$ kointegrációs kapcsolatot mutat, azonban a nyomteszt eredményei $(\eta)$ éppen a nullhipotézis elutasításának határán mozognak. A súlyozott relatív szórásnál egyértelmű a helyzet, ugyanis ott a tesztek egyáltalán nem mutatnak kointegrációt. 2002 után a tesztek eredményei egybehangzóvá válnak, a kointegráció hiányának nullhipotézise minden esetben megállja a helyét, s az első differenciák korrelációs együtthatói is 0 körül mozognak.

A trendtörések beiktatásával megismételt számítás kissé ellentmondásos eredményei igen megnehezítik az interpretációt. Nem bizonyítható ugyanis egyértelműen, hogy hazánkban a rendszerváltás után rögtön kialakult volna a gazdasági teljesítmény és a munkanélküliség területi egyenlőtlenségei között olyan kapcsolat, mely a fejlett piacgazdaságokban érzékelhető és statisztikai 
5. táblázat: A trendtöréssel felbontott időszakok korrelációs együtthatói és a VECM-modell eredményei

Correlation coefficients and the results of the VECM-model of the divided time series

\begin{tabular}{l|rrr|rrr}
\hline \multirow{2}{*}{ Változópárok } & \multicolumn{3}{|c|}{$1992-2001$} & \multicolumn{3}{c}{$2002-2010$} \\
\cline { 2 - 7 } & $\operatorname{corr}(\Delta U)$ & $(\eta)$ & $\left(\lambda_{\max }\right)$ & $\operatorname{corr}(\Delta U)$ & \multicolumn{1}{c}{$(\eta)$} & $\left(\lambda_{\max }\right)$ \\
\hline Országos munkanélküliségi ráta & $-0,3434$ & 15,1097 & 15,0951 & 0,0524 & 3,6776 & 3,4943 \\
$\quad$ - relatív diszperzió & $(0,0001)$ & $(0,0571)$ & $(0,0369)$ & $(0,5904)$ & $(0,9278)$ & $(0,9085)$ \\
Országos munkanélküliségi ráta & $-0,3753$ & 7,6550 & 7,6523 & 0,04411 & 2,7268 & 2,6647 \\
$\quad$ - súlyozott relatív szórás & $(0,0000)$ & $(0,5041)$ & $(0,4173)$ & $(0,6504)$ & $(0,9779)$ & $(0,9665)$ \\
\hline
\end{tabular}

Megjegyzés: lásd 3. táblázat.

eszközökkel kimutatható. Mivel 2002-ig sem sikerült egyértelmű bizonyítékot találni a változóink közötti kointegrációra vagy megfelelő erősségü és irányú korrelációkra, az ezredforduló utáni állami beavatkozás feltételezett szerepe is veszít jelentőségéből.

Jelen vizsgálat eredményei szerint tehát elvethető az a felvetés, miszerint az elmúlt 21 évben kapcsolat mutatkozna a gazdasági teljesítmény és a munkanélküliség területi egyenlőtlenségei között. Az átmeneti időszak egyedi gazdasági mechanizmusai és az állami kiigazítások fényében a rendszerváltozás óta eltelt két évtized tapasztalatai nem adnak kellő támpontot ahhoz, hogy kijelentsük, a gazdasági teljesítmény és a munkaerőpiac területi különbségei között statisztikai eszközökkel kimutathatóan létrejöhetett a fejlett piacgazdaságokban (pl. Egyesült Királyság, Ausztrália, Finnország) tapasztalható azonos - illetve az országos munkanélküliségi rátával ellentétes - irányú kapcsolat. A jelenség kialakulása tehát hazánkban egyelőre nem tapasztalható, azonban mindenképp le kell szögezni, hogy a folyamatot az állami beavatkozások mellett egyéb látens, trendtörésekkel nem leírható tényezők is aktívan befolyásolhatták, melyek azonosítása és mérése igen nehéz feladat. A gazdasági teljesítmény és a munkanélküliség regionális egyenlőtlenségei között feltételezett kapcsolatok kimutatása minden bizonnyal évek elteltével válik lehetségessé, amikor megfelelő hosszúságú idősor áll majd rendelkezésre az összetettebb, több tényezőt is magába foglaló vizsgálatokhoz.

\section{Összefoglalás}

A fejlett piacgazdaságokban a makrogazdasági teljesítmény és a munkapiacok területi különbségei között fennálló egyensúlyi kapcsolatok az elmúlt évtizedekben több helyütt bizonyítást nyertek. Magyarország esetében ugyanakkor egyelőre nem beszélhetünk effajta egzakt kapcsolatról, a rendszerváltás utáni átmenet reálgazdasági folyamatai és a fokozott állami befolyás közepette elmaradt annak kialakulása. Az alkalmazott ökonometriai módszerek sem a rendel- 
kezésre álló időszak egészére, sem annak szegmenseire nem adtak a kapcsolatok létezésére utaló eredményeket. A korrelációs vizsgálatok tapasztalatai alapján egyedül 2002-ig volt megfigyelhető minimális kapcsolat, amit a kointegrációs tesztek csak részben, az egyik egyenlőtlenségi mutatónál támasztottak alá. Mindezek alapján, valamint a hozzáférhető idősorok vizsgálati korlátainak figyelembevétele mellett megállapítható, hogy a keresett egyensúlyi kapcsolatok kialakulásához az elmúlt két évtized nem volt elegendő, azonban kérdés, hogy ez az állapot teljesen kifejlett, a nyugatihoz hasonló piacgazdasági keretek között és a 2008-as válság hatására hogyan módosul. Ennek feltárása a jövőben további vizsgálatokat kíván.

\section{Jegyzetek}

1 A tanulmányban felhasznált adatok a Nemzetközi Munkaügyi Szervezet (ILO) iránymutatásai alapján készült becslésekből származnak. A bemeneti oldalon az NFSZ nyilvántartott munkanélküliek számára vonatkozó települési szintű adatok, a KSH munkaerő-felmérés személyi szintű adatai és a népszámlálásból továbbvezetett népességi adatok találhatók, melyekből az NFSZ a munkanélküliségre, a foglalkoztatásra és a gazdasági aktivitásra becsül abszolút és relatív mutatókat.

2 Munkámban a mutatóra történő utaláskor szándékosan használom az angol megnevezés (relative dispersion) tükörfordítását, hiszen a „dispersion” kifejezés magyar megfelelői, a „szórás, szóródás, elszórtság" kifejezések esetleg félreértésre adhatnának okot.

3 A Hoover-index két mennyiségi ismérv területi eloszlásának eltéréseit vizsgálja. Képlete $H=\frac{\sum\left|x_{i}-f_{i}\right|}{2}$, ahol $x_{i}$ és $f_{i}$ megoszlási viszonyszámok. Minél magasabb a mutató értéke, annál

nagyobb az ismérvek közti területi különbség. Értékkészlete: [0 $\leq \mathrm{H} \leq 100]$. A mutatóról és alkalmazási lehetőségeiről bővebben lásd: Nemes Nagy (2005).

4 A súlyozott relatív szórás esetében a 100-zal való szorzást kényelmi szempontból elhagytam, hogy a két, ábrán szereplő mutató azonos nagyságrendben maradjon. A módosított képlet így a következőképpen fest: $\sigma=\left(\frac{1}{x^{\prime}}\right) \sqrt{\frac{\sum f_{i}\left(x_{i}-x^{\prime}\right)^{2}}{\sum f_{i}}}$, ahol $x_{i}$ a munkanélküliségi ráta és $f_{i}$ a gazdaságilag aktívak száma $i$ területegységben, $x$ ' pedig a munkanélküliségi ráta országos átlaga.

5 Valós esetekben a paraméter egységnél magasabb értékeket nem vehet fel, ugyanis abban az esetben a modell „szétrobbanna”, azaz Y értéke a végtelenbe tartana.

6 A kiterjesztett Dickey-Fuller-teszt összefoglalását lásd pl. Maddala $(2004,615$.$) .$

7 A VECM származtatásának matematikai levezetést lásd pl. Hamilton (1994, 580).

8 A Granger-tételekről és bizonyításukról lásd pl. Johansen (2000).

9 Lásd pl. Hamilton (1994, 645-650.).

\section{Irodalom}

Ábrahám Á., Kertesi G. (1996): A munkanélküliség regionális egyenlőtlenségei Magyarországon 1990-1995 között. A foglalkoztatási diszkrimináció és az emberi tőke váltakozó szerepe. 
Közgazdasági Szemle, 7-8., 653-681.

Baddaley, M., Martin, R., Tyler, P. (1998): Transitory shock or structural shift? The impact of the early 1980s recession on British regional unemployment. Applied Economics, 1., 19-30.

Christiano, L. (1992): Searching for breaks in GNP. Journal of Business and Economic Statistics, 3., 237-250.

Dixon, R., Mahmood, M. (2007): Unemployment rate dispersion in Melbourne: the regional dimension. University of Melbourne, Department of Economics, Melbourne (Research Papers; 983.)

Dixon, R., Shepherd, D., Thomson, J. (2001): Regional unemployment disparities in Australia. Regional Studies, 2., 93-102.

Fazekas K. (1997): Válság és prosperitás a munkaerőpiacon. A munkanélküliség regionális sajátosságai Magyarországon 1990-1996 között. Tér és Társadalom, 4., 9-24.

Fazekas K., Németh N. (2005): A regionális különbségek csökkentése. In: Köllő J. (szerk.): A magyar foglalkoztatáspolitika átfogó értékelése az Európai Foglalkoztatási Stratégia kontextusában, az elmúlt öt év tapasztalatai alapján. FMM, Budapest, 266-285.

Gleave, D. (1987): Dynamics in spatial variations of unemployment. In: Fisher, M. M., Nijkamp, P. (eds.): Regional labour markets: analytical contributions and cross-national comparisons. NorthHolland, Amsterdam, 269-288.

Granger, C., Newbold, P. (1974): Spurious regressions in econometrics. Journal of Econometrics, 2., 111-120.

Hamilton, J. (1994): Time series analysis. Princeton University Press, New York

Johansen, S. (1988): Statistical analysis of cointegration vectors. Journal of Economic Dynamics and Control, 2-3., 231-254.

Johansen, S. (2000): Modelling of cointegration in the vector autoregressive model. Economic Modelling, 3., 359-373.

Kormos J., Czeglédi P. (2008): A munkaerőpiaci rugalmatlanság és a munkanélküliségi idősorok egységgyök-tulajdonsága: problémafelvetés. Competitio, 2., 103-113.

Köllő J., Kertesi G. (2004): A 2001. évi minimálbér-emelés foglalkoztatási következményei. Közgazdasági Szemle, 4., 293-324.

Lőcsei H. (2010): A gazdasági világválság hatása a munkanélküliség területi egyenlőtlenségeire. In: Fazekas K., Molnár Gy. (szerk.): Munkaerőpiaci tükör 2010. MTA KTI, Országos Foglalkoztatási Közalapítvány, Budapest, 126-141.

Maddala, G. (2004): Bevezetés az ökonometriába. Nemzeti Tankönyvkiadó, Budapest

Martin, R. (1997): Regional unemployment disparities and their dynamics. Regional Studies, 3., 237-252.

Nelson, C., Plosser, C. (1982): Trends and random walks in macroeconomic time series: some evidence and implications. Journal of Monetary Economics, 2., 139-162.

Nemes Nagy J. (szerk.) (2005): Regionális elemzési módszerek. ELTE Regionális Földrajzi Tanszék, Budapest (Regionális Tudományi Tanulmányok; 11.)

Nemes Nagy J., Németh N. (2005): Az átmeneti és az új térszerkezet tagoló tényezői. In: Faluvégi A., Fazekas K., Nemes Nagy J., Németh N. (szerk.): A hely és a fej. Munkaerőpiac és regionalitás Magyarországon. MTA KTI, Budapest, 75-137.

Pehkonen, J., Tervo, H. (1998): Persistence and turnover in regional unemployment disparities. Regional Studies, 5., 445-458.

Schwertner J. (1994): Parázsló munkaerőpiac. Tér és Társadalom, 1-2., 59-82.

Williamson, S. (2009): Makroökonómia. Osiris Kiadó, Budapest 